\title{
Anaesthesia for the aging patient
}

The most important advance in our understanding of the anaesthetic implications of aging has been recognition of the need to distinguish clearly between processes of aging as opposed to age-related disease. Those consequences of altered tissue and organ system structure and function which are universally observed in all elderly individuals, and which increase in severity or magnitude with advancing years, reflect aging per se. On the other hand, changes in structure or function which are not seen in all members of a geriatric population, or those changes which do not appear to have a direct relationship between severity and chronological age, are probably due to agerelated disease.

Aging produces generalized changes in virtually every subcellular, cellular, and tissue element, but certain organs have particularly pronounced and clearly defined age-related alterations of function or of functional reserve. The organs most relevant to anaesthetic practice are the brain and peripheral nervous system, the lungs and cardiovascular system, the hepatic and renal systems, and the sympathoadrenal mechanisms which maintain autonomic homeostasis of haemodynamics and respiration. This review will provide an overview of current concepts in physiology of aging, a summary of common agerelated disease processes, and an assessment of their relationship to the anaesthetic management of the elderly patient.

\section{Nervous system}

The nervous system is the target organ for virtually every anaesthetic drug and adjuvant, and therefore age-related changes in nervous system function have direct and important implications for the anesthetic plan of an elderly patient. Aging appears to compromise nervous system functional reserve and to alter the response to anaesthetic agents and perioperative stress far more than it degrades day-to-day function. Specific effects of aging on the nervous system include (1) selective attrition of cerebral and cerebellar cortical neurons, with progressive neuron loss within certain areas of the thalamus, locus ceruleus, and basal ganglia: aging produces a generalized reduction in neuron density and loss of $30 \%$ of gross brain mass by the age of $80 \mathrm{yr}$, with atrophy especially evident in the grey matter; (2) generalized depletion of catecholamines, serotonin, acetylcholine and other brain neurotransmitters due to attrition within neurotransmitter-synthesizing areas and a generally reduced rate of biochemical synthesis. Transmitter destruction by endogenous catabolic enzymes, in contrast, appears to occur at an accelerated rate; (3) loss of peripheral, motor, sensory, autonomic nerve fibres and diffuse axonal "drop out," with subsequent reduction in both afferent and efferent nerve conduction velocities and some reduction in the rate of signal processing within brain stem and spinal cord; (4) impaired proximo-distal protoplasmic transport of amino acids and neuropeptides within nerve axons: reduced myotrophism of skeletal muscle produces disseminated neurogenic atrophy, seen as proliferation of muscle endplates and "up-regulation" (increased numbers of peripheral nicotinic cholinergic receptors); and (5) a generalized deafferentation: progressive increases in the activation thresholds needed for the special sense organs responsible for vision, hearing, touch, joint position sense, smell, and peripheral pain and temperature.

Nevertheless, global integrated nervous system functions such as intelligence, personality, and memory are comparable to those of young adults. There is, however, moderate compromise of "fluid" intelligence which requires rapid mental manoeuvres or retrieval of stored information. The intrinsic mechanism by which the brain closely couples neuronal activity, metabolism, and blood flow also appears to remain grossly intact, at least in the absence of disease, as does cerebrovascular responsiveness to carbon dioxide. Therefore, in healthy elderly individuals reduced cerebral blood flow is an appropriate response to decreased cerebral metabolic demands, and not, as was once believed, a manifestation of inevitable, senile "hardening of the arteries." Specific brain and spinal cord blood flow and oxygen consumption (both expressed per $100 \mathrm{~g}$ of brain tissue) do exhibit a slight, parallel decline, with glucose utilization falling at a slightly faster rate. Because total nervous system mass and neuronal tissue density also decline in the aging subject, absolute brain blood flow, which reaches its maximum value in the fourth decade of life, is reduced significantly ( 20 to $40 \%$ ) by the age of $80 \mathrm{yr}$.

Anaesthetic requirement under equilibrium conditions can be quantified and compared by looking for changes

From the Hospital of the University of Pennsylvania, Philadelphia, Pennsylvania. 
TABLE Adjustments of anaesthetic and adjuvant drugs in elderly patients

\begin{tabular}{|c|c|}
\hline Drug group & Adjustments needed \\
\hline Potent inhalational agents & Decrease inspired concentrations, allow more time for emergence \\
\hline Barbiturates, etomidate, propofol, althesin & Small to moderate decrease in initial dose; reduce infusion rates \\
\hline Narcotics & $\begin{array}{l}\text { Marked decrease in initial dose; anticipate increased duration of systemic and epidural } \\
\text { effects, greater incidence of rigidity and respiratory depression }\end{array}$ \\
\hline Local anaesthetics for spinal/epidural anaesthesia & Small to moderate decrease in segmental dose requirement; anticipate prolonged effects \\
\hline Benzodiazepines & Modest decrease in initial dose; anticipate marked increase in duration (except midazolam) \\
\hline Succinylcholine & Slightly reduced dose in elderly men \\
\hline Nondepolarizing relaxants & $\begin{array}{l}\text { Same or slight increase in initial dose; anticipate increased duration (except atracurium or } \\
\text { mivacurium) }\end{array}$ \\
\hline Neostigmine, edrophonium & $\begin{array}{l}\text { No change in dose or efficacy; slightly prolonged effect, anticipate postoperative } \\
\text { bradyarrhythmias }\end{array}$ \\
\hline Atropine & Increased dose for equal heart rate response, anticipate central anticholinergic syndrome \\
\hline $\begin{array}{l}\text { Epinephrine, isoproterenol, other adrenergic agonists; } \\
\text { beta agonists }\end{array}$ & Increased doses for equal cardiovascular responses \\
\hline
\end{tabular}

in median effective dose $\left(\mathrm{Ed}_{50}\right) ; M A C$, the $\mathrm{ED}_{50}$ equivalent for inhalational anaesthetics, falls linearly with increasing age, beginning in young adulthood. This reduction in the requirement for general anaesthetics has been demonstrated in human subjects receiving halothane, isoflurane, cyclopropane, and desflurane. The rate at which aging reduces MAC appears to be the same for all these agents; therefore, the reduction in anaesthetic requirement is agent-independent, and is probably due to fundamental neurophysiological changes within the brain, such as reduced neuron density or, more likely, altered concentrations of brain neurotransmitters. Anaesthetic requirement may, in fact, be the only quantifiable measure of the functional reserve of the central nervous system. Typically, an 80-yr-old patient will require only two-thirds to three-quarters of the anaesthetic concentration needed to produce comparable effects in a young adult (Table).

Some of the reported age-related changes in requirement for intravenous anaesthetics such as thiopentone and etomidate may simply be due to the higher-than-expected initial plasma concentrations of these drugs which have been observed during the early phases of their redistribution from plasma to body tissues. Thus, the reduced dose requirement can be explained, at least in part, as a pharmacokinetic, rather than a pharmacodynamic event. However, other studies of the relationship between drug effect and plasma concentration for benzodiazepines and for the effects of near steady-state infusions of narcotics and propofol also support the concept that aging produces a true alteration of pharmacodynamics in elderly individuals, a reduction of anaesthetic requirement comparable to that observed for inhalational agents.
The classic two- and three-compartment models used for pharmacokinetic analysis of intravenous anaesthetics have also been less predictive of actual clinical responses than had been hoped, leading to extensive reevaluation. of assumptions that age simply alters the size of the "lipophilic" and "hydrophilic" drug disposition volumes. More recently, modification of traditional pharmacokinetic compartment models with emphasis upon altered rates of transfer between compartments, rather than the size or the number of the compartments themselves, has been proposed to provide more accurate predictions of drug dispositions in elderly subjects. The mechanism of altered rate of transfer is unknown.

The most common nervous system disorders seen in a geriatric population, Parkinsonism and Alzheimer's dementia, reflect specific neurotransmitter deficits. Their prevalence may be amplified by the normal processes of neurotransmitter depletion which occur with advancing years even in normal subjects. Cerebrovascular disease seems to be the most common aetiology for the remainder of age-related nervous disorders: typically, $6 \%$ of the geriatric surgical population present at time of surgery with a history of cerebral vascular accident. Stroke or other neurological ischaemic phenomena account for $3 \%$ of perioperative mortality in these patients. However, the low rate of spontaneous intraoperative cerebrovascular accidents in healthy elderly surgical patients, despite their well-known predisposition to haemodynamic instability and autonomic impairment, suggest that cerebral blood flow autoregulation is minimally compromised by age itself.

The blood-brain-barrier also remains functionally in- 
tact. Therefore, the most common cause of prolonged depression of consciousness, disorientation, autonomic instability, hyperreflexia, or other manifestations of acute postoperative nervous system dysfunction in elderly patients is, simply stated, residual anaesthetic drug effects. In a geriatric surgical population, this form of anaesthetic morbidity may be observed more frequently than in younger patients, and may be more persistent, because there is age-related compromise of organ system function which delays drug elimination. In addition, the reduced central nervous system functional reserve of elderly patients amplifies the effects of even low residual tissue concentrations of these potent drugs.

\section{Cardiovascular system}

Integrated cardiovascular function changes less than does cardiac and vascular structure anatomy. Classic data suggested a relentless decline in resting cardiac index with advancing age. More recent studies indicate that normally active, adequately conditioned elderly individuals maintain a resting cardiac index at levels almost indistinguishable from their younger counterparts; cardiac output is slightly reduced, but in proportion to the decreased skeletal muscle mass and reduced body surface area seen in an aged population. At submaximal levels of demand, there are also no consistent age-related reductions of velocity of myocardial shortening or rate of ventricular pressure generation. In other words, ventricular "pump function" appears to be largely a reflection of conditioning and aerobic demand, rather than chronologic age.

In the elderly subject, cardiac output is enhanced during exercise in part by increased heart rate, but also by a unique additional ability to augment left ventricular diastolic volume in response to rising preload, probably through the Frank-Starling mechanism. In young adults, in contrast, most of the increase in cardiac output which occurs in response to exercise reflects increase in heart rate and the enhancement of ejection fraction by the neural and humoral components of the sympathoadrenal nervous system. However, the chronotropic and inotropic effects of beta agonist drugs are significantly reduced in elderly individuals. On an adrenergic level, aging can therefore be thought of as a state of progressively more pronounced beta adrenergic blockade. The homeostatic baroreflex mechanisms which increase the rate or the velocity of myocardial contraction in young adults also diminish in effectiveness with advancing age. Impaired adrenergic receptor quality, not decline in number of receptors, is thought to be the mechanism responsible for these changes, since the potency of both adrenergic agonists and their antagonists have been shown to be decreased in elderly subjects.

In healthy individuals, the other major age-related change in cardiovascular function is a loss of large artery elasticity which produces hydraulic stiffening of the arterial tree. As a consequence, there is a progressive rise in systolic arterial blood pressure and a widening of pulse pressure; this increased impedance to the ejection of stroke volume produces concentric hypertrophy of the left ventricular myocardial wall. Some fibrotic infiltration of cardiac conduction pathways also predisposes the elderly patient to conduction delay and to arterial and ventricular ectopy. Reduced elasticity and fibrotic change within the hypertrophic heart itself further reduce ventricular compliance, making the aged heart at once both volumesensitive and volume-intolerant. Because small fluctuations in the volume of venous return produce large changes in ventricular "preload" pressures, elderly patients are particularly predisposed to arterial hypotension when there is interruption of venous return, yet are also more likely to experience rapid increases in diastolic pressures and distentions of cardiac chambers when venous return is vigorously augmented, or when intravenous volume replacement therapy is excessive. Loss of atrial "kick" can critically compromise stroke volume and cardiac output.

Some degree of age-related reduction in arterial elasticity is seen even in populations in which pathologic arteriosclerosis is virtually unknown. In our society, however, diet and environmental conditions make hypertension and arteriosclerotic disease, with or without myocardial ischaemia, the most common expression of agerelated pathology in the geriatric surgical population. Fully half of all elderly patients have preoperative evidence of this type of age-related disease, and it may account for $10 \%$ of perioperative mortality in a geriatric surgical population.

\section{Respiratory system}

The functional consequences of aging on pulmonary function, although complex, can be largely attributed to a generalized loss of lung elastic recoil. Even in elderly patients who are free of definable pulmonary disease, emphysema-like increases in lung compliance disrupt the precise matching of ventilation and perfusion, leading to increased physiologic shunting and reduced efficiency of oxygen exchange. Although oxygen diffusion through the lung itself appears to be unchanged, maldistribution of pulmonary blood flow relative to the distribution of tidal volume causes arterial oxygen tension to fall linearly with age, a phenomenon which has been repeatedly demonstrated in patients before, during, and after surgery. Carbon dioxide excretion is essentially unaffected, however, and arterial carbon dioxide levels in elderly subjects remain identical to those in young adults, suggesting normal moment-to-moment regulation of ventilation and carbon 
dioxide responsiveness. However, elderly subjects do demonstrate marked suppression of the hyperventilation seen in children and young adults in response to imposed hypoxia or hypercapnia, and therefore the elderly patient is at greater risk of unsuspected perioperative ventilatory failure.

Despite the age-related loss of lung elasticity and increased lung compliance, total pulmonary compliance remains virtually unchanged, since aging produces progressive fibrocalcification of the thoracic cage and thereby reduces the compliance of the chest wall. Atrophy of intracostal muscles further impairs the effectiveness of the respiratory "bellows," imposing an age-related restrictive quality upon pulmonary mechanics, a change most evident as a fall in $\mathrm{FEV}_{1}$ and in mid-maximal expiratory flow (MMEF). About $15 \%$ of the geriatric surgical population also presents with evidence of chronic obstructive pulmonary disease preoperatively, and pre-existing lung disease, along with the site of surgery, have long been known to be the two most accurate predictors of postoperative pulmonary morbidity and mortality.

\section{Renal system}

Aging alters renal function to a great extent, largely because it has a profound effect on the state of the renal vasculature. Despite a relatively modest loss of total renal tissue mass (about $10-20 \%$ by the age of $80 \mathrm{yr}$ ), aging produces a significant, virtually linear decline in glomerular filtration rate (GFR) of 6-8\% per decade of life. When measured longitudinally over long periods of time in healthy volunteer subjects, renal blood and plasma flow both demonstrate a dramatic and progressive age-related decline: in subjects $80 \mathrm{yr}$ of age, these indices have fallen to about one-half the values observed in young adults. Filtration fraction, however, does rise slightly, somewhat offsetting this marked reduction in renal perfusion. Anatomically, there is a moderate degree of glomerular obliteration and disruption of renal vascular architecture, with a significant loss of functioning nephron units. Active tubular secretion and reabsorption of drugs and other solutes therefore declines proportionally. The speed and magnitude of the renal/pituitary response to dehydration is also significantly compromised in elderly subjects, with marked impairment of the ability to concentrate the urine and to conserve free water.

Much of this age-related renal compromise is undetected by routine laboratory "screening" tests. The reduced creatinine load associated with the shrinking skeletal muscle mass seen in elderly patients yields net serum creatinine concentrations which are virtually indistinguishable from those of young adults. Thus, under normal circumstances, while there is sufficient residual renal function to avoid gross azotemia or uremia, the renal functional reserve needed to withstand imposed water and electrolyte imbalance in elderly patients is minimal. In fact, acute renal failure is responsible for at least onefifth of the perioperative mortality in elderly surgical patients. The pharmacological consequences of age-related changes in renal function are more significant: the elimination half-time $\left(t_{1 / 2} \beta\right)$ of virtually every anaesthetic drug and metabolite normally cleared by renal mechanisms is prolonged in elderly patients, especially in those who present with pre-existing renal dysfunction.

\section{Hepatic system}

Qualitatively, there is little change in hepatocellular function with advancing age. In normal individuals, microsomal and non-microsomal enzyme activity appears to be well-preserved, although hepatic synthesis of plasma cholinesterase is deficient in many elderly men. Older women seem better able to maintain their enzymatic function at levels hear those seen in young adults, and are also more likely than men to exhibit the smoking-induced enzyme induction which can produce enhanced rates of drug biotransformation. Nevertheless, in all elderly subjects, aging produces a marked reduction in liver size, and as much as $40-50 \%$ of young adult hepatic tissue mass may involute by the age of 80 , with liver blood flow proportionally reduced.

This loss of well-perfused hepatic tissue appears to play the major role in age-related declines in rates of drug clearance for those anaesthetics and adjuvants which require hepatic biotransformation, especially those which utilize a "first-pass" mechanism. The duration of the clinical effect of these intravenous agents may be further prolonged if their primary or secondary metabolites subsequently undergo renal elimination. Overt hepatic dysfunction and failure appear in a small but significant fraction of elderly surgical patients (about $4 \%$ ), but more subtle degrees of hepatic compromise and limited hepatic functional reserve explain many postoperative complications and may require supportive therapy and intensive care.

\section{Sympathoadrenal axis}

Plasma epinephrine and norepinephrine are elevated consistently and significantly, both at rest and in response to stress, in older adults. Nevertheless, elderly subjects do not appear to be functionally "hyper-adrenergic" because these high levels of catecholamines only partially compensate for the reduced responsiveness of autonomic end-organs. Consequently, the speed, magnitude, and efficacy of autonomic homeostasis is progressively impaired with increasing age. There appears to be no peripheral "down-regulation" of adrenoceptors despite increased exposure to their agonist molecules. It is not clear whether 
these age-related phenomena are due to a loss of affinity between catecholamines and peripheral adrenoceptors, or whether reduced end-organ responsiveness represents a relative failure of adenylate cyclase activation at a cellular level.

Whatever the mechanism, homeostatic hypothalamic set-points for blood pressure and heart rate do not appear to change with increasing age, but autonomic systems begin to behave in an "underdamped" fashion: there are wider swings in blood pressure than occur in young adults, and both hypotension and hypertension produce reflex responses in heart rate which are smaller in magnitude, less timely, and less effective in providing constant organ perfusion pressures. Consequently, anaesthetic agents and techniques which further depress autonomic end-organ function, suppress endogenous catecholamine levels, produce ganglionic blockade, or create a pharmacologic sympathectomy are all associated with a greater frequency and severity of hypotension in elderly patients than in young adults. Similarly, arterial hypertension following painful stimulation tends to be more extreme, and to subside less rapidly, in elderly than in young patients.

\section{Body composition}

Important age-related changes in body composition include a poorly understood intracellular process of dehydration, atrophy of skeletal muscle, and an increase in the lipid fraction of total body weight. Long-term studies suggest that, on average, $6 \mathrm{~kg}$ of skeletal muscle are lost, $5 \mathrm{~kg}$ of adipose are gained, and total body water is reduced $12 \%$ by the age of $80 \mathrm{yr}$. The changes are greater in women than in men. Changes in body composition influence anaesthetic pharmacokinetics because they increase the fraction of body mass which acts as a reservoir for lipid-soluble drug molecules. If the distribution volume of a narcotic or lipid-soluble agent is significantly enlarged, the time required for its subsequent elimination, even when the rate of its clearance from plasma is unchanged, is increased. If, in addition, the clearance of a drug from plasma is impaired because of age-related loss of hepatic mass or reduced renal perfusion, the net effect is an even greater prolongation of $t_{1 / 2} \beta$, and an increased duration of clinical drug effect. Only molecules with particularly high solubility in specialized lipid compartments such as brain and spinal cord or those with very high receptor affinities demonstrate unchanged steady-state distribution volumes when administered to elderly patients.

\section{Physical status and anaesthetic outcome}

Anaesthetic-related mortality is higher in the elderly than in the young adult surgical patient. However, recent re- views of data for perioperative mortality as a function of physical status suggests that age-related disease, not aging itself, actually plays the most important role in this relationship. In patients with severe end-stage disease or those with multiple organ system failures, the loss of autonomic homeostasis intrinsic to aging may act as an additional age-related factor which increases perioperative risk. There is no "best" anaesthetic for elderly patients. Large-scale, prospective, randomized studies of contemporary anaesthetic practice fail to suggest any clinically or statistically significant advantage to regional as opposed to general anaesthesia. Similarly, there is no evidence to support the preferential selection of a specific general anaesthetic agent. The use of pharmacological sympathectomy with epidural local anaesthetics to minimize postsurgical pain and stress responses may, however, provide large reductions in perioperative morbidity.

In general, age can no longer be considered a contraindication to anaesthesia and surgery. Further progress in identifying age-related disease will ultimately reveal those specific sources of risk which, unlike aging itself, can be minimized or eliminated.

\section{Suggested reading}

Aronow WS, Stein PD, Sabbah HN, Koenigsberg M. Resting left ventricular ejection fraction in elderly patients without evidence of heart disease. Am J Cardiol 1989; 63: 368-9.

Collins KJ, Exton-Smith AN, James $M H$. Functional changes in autonomic nervous responses with ageing. Age and Ageing 1980; 9: 17-24.

Creasey H, and Rapoport SI. The aging human brain. Ann Neurol 1985; 17: 2-10.

Davis FM, Woolner DF, Frampton C, Wilkinson A, Grant A, Harrison RT. Prospective, multi-centre trial of mortality following general or spinal anaesthesia for hip fracture surgery in the elderly. Br J Anaesth 1987; 59: 1080-8.

Forrest JB, Rehder K, Cahalan MK, Goldsmith CH. Multicenter study of general anaesthesia. III. Predictors of severe perioperative adverse outcomes. Anesthesiology 1992; 76: 3-15.

Fulop T Jr, Worum I, Csongor J, Foris G, Leovey A. Body composition in elderly people. Gerontology $1985 ; 31: 6-14$.

Hayflick $L$. Biologic and theoretical perspectives of human aging. In: Katlic MR (Ed.). Geriatric Surgery: Comprehensive Care of the Elderly Patient. Baltimore: Urban and Schwarzenberg 1990; 3-21.

Lassen NA, Ingvar DH, Skinhoj E. Brain function and blood flow. Scientific American 1978; 239: 62-71.

Lewin I, Lerner AG, Green SH, Del Guercio LRM, Siegel JH Physical class and physiologic status in the prediction of operative mortality in the aged sick. Ann Surg 1971; 174: 217-31.

McLachlan MSF. The aging kidney. Lancet 1978; 2: 143-6. 
Muravchick $S$. Immediate and long-term nervous system effects of anaesthesia in elderly patients. Clin Anaesth 1986; 4: 1035-45.

Muravchick S, Stephen CR. Anesthesia for the geriatric patient. Chapter 28. In: Nunn JF, Utting JE, Brown BR Jr.

(Eds.). General Anaesthesia, 5th edition. London: Butterworths 1989; 803-13.

Vestal RE, Wood AJJ, Shand DG. Reduced adrenoceptor sensitivity in the elderly. Clin Pharmacol Ther 1979; 26: 181-6.

Wahba WM. Influence of aging on lung function - clinical significance of changes from age twenty. Anesth Analg 1983; 62: 764-79. 
Stanley Muravchick MD PhD

\section{L'anesthésie du patient âgé}

Pour bien comprendre les répercussions de l'anesthésie sur le vieillissement, il fallait reconnaître la distinction nette qui existe entre le vieillissement et les maladies qui lui sont rattachées. Chez l'individu âgé, les conséquences des changements structurels et fonctionnels tissulaires et organiques sont universellement reconnues. Ces altérations progressent avec l'âge et sont un reflet de l'âge lui-même. Cependant, on ne retrouve pas certains changements de structures et de fonctions chez tous les membres de la population gériatrique, ou on en retrouve qui ne présentent pas de relation directe avec l'âge chronologique. Ce sont selon toute probabilité des maladies rattachées à l'âge.

Le vieillissement produit des changements généralisés dans tous les composantes intra-cellulaires, cellulaires et tissulaires. Certains organes ont des altérations de fonction et de réserve fonctionnelle plus importantes et plus spécifiques à l'âge. Les organes les plus préoccupants pour l'anesthésiste sont le cerveau et le tissu nerveux périphérique, les poumons et le système cardio-vasculaire, les systèmes rénal et hépatique, et les mécanismes sympathico-adrénergiques qui maintiennent l'homéostase de l'hémodynamique et de la respiration. Ce tour d'horizon expose les concepts actuels de la physiologie du vieillissement, un synopsis des maladies communes à l'âge et une évaluation de leur relation avec la conduite anesthésique qui s'appliquent au malade âgé.

\section{Le système nerveux}

Le système nerveux est l'organe-cible de la plupart des drogues anesthésiques. Les altérations du système nerveux en rapport avec l'âge ont, par le fait même, des répercussions sur la conduite anesthésique. La sénescence compromet la réserve fonctionnelle du système nerveux et altére la réponse aux agents anesthésiques et au stress opératoire beaucoup plus qu'elle ne détériore le mode de vie quotidien. Les effets spécifiques du vieillissement sur le système nerveux se résument ainsi: 1) la disparition sélective des neurones cérébraux et cérébelleux avec perte progressive de neurones dans certaines régions du thalamus, du locus ceruleus et des ganglions de la base. Le vieillissement provoque une réduction générale de la densité neuronale et une perte de $30 \%$ de la masse cérébrale à l'âge de 80 ans, avec une atrophie particulièrement importante de la substance grise; 2) la déplétion généralisée des catécholamines, de la sérotonine, de l'acétylcholine et autres neurotransmetteurs par attrition des zones de synthèse et une réduction généralisée de la synthèse biochimique elle-même. Par contraste, la destruction par les enzymes catabolisantes semble s'accélérer; 3) les pertes des fibres nerveuses périphériques, motrices, sensorielles, autonomes et le " lâchage " axonal diffus avec une réduction subséquente des vélocités nerveuses afférentes et efférentes et une réduction de la vitesse de traitement des signaux reçus par le bulbe et la moelle épinière; 4) la détérioration du mécanisme de transport protoplasmique proximo-distal des acides aminés et des neuropeptides axonaux. La baisse du myotrophisme musculaire squelettique provoque une atrophie neurogène disséminée manifestée par la prolifération des plaques motrices; 5) la déafférentation généralisée: élévation progressive des seuils d'activation nécessaires au fonctionnement des organes des sens responsables de la vision, l'audition, le toucher, l'odorat, de la proprioception, de la douleur périphérique et de la température.

Néanmoins, les fonctions globales intégrées du système nerveux comme l'intelligence, la personnalité et la mémoire se comparent à celles d'adultes jeunes. Il existe toutefois une détérioration modérée de l'intelligence " fluide " qui nécessite des manoeuvres mentales rapides et la récupération d'éléments gardés en mémoire. Les mécanismes intrinsèques par lesquels le cerveau apparie l'activité neuronale, le métabolisme et le débit sanguin semblent généralement intacts, du moins en absence de maladies, de même que la réponse cérébro-vasculaire au gaz carbonique. Chez l'individu âgé, la baisse du débit sanguin cérébral est donc une réponse appropriée à la demande métabolique qui diminue, et non comme on l'a déjà cru, à une manifestation de l'inexorable durcissement sénile des artères. Le débit sanguin régional cérébral et médullaire ainsi que la consommation d'oxygène (exprimés en $100 \mathrm{~g}$ de tissu cérébral) déclinent légèrement parallèlement à l'utilisation du glucose qui baisse un peu plus rapidement. Comme la masse totale et la densité neuronale tombent aussi, le débit sanguin cérébral absolu qui atteint son maximum pendant la quatrième décennie diminue sensiblement à quatre-vingts ans (de 20 à 40\%).

Les besoins anesthésiques à l'état stable peuvent être évalués et comparés en étudiant les modifications de la dose efficace médiane $\left(\mathrm{ED}_{50}\right)$; la $\mathrm{CAM}$, qui équivaut pour l'anesthésie à l'ED ${ }_{50}$ diminue de façon linéaire avec l'âge avec son début à l'âge du jeune adulte. Cette réduction 
TABLEAU Ajustements des drogues et adjuvants en relation avec le vieillissement

\begin{tabular}{|c|c|}
\hline Drogues & Ajustement requis \\
\hline Agents anesthésiques & Diminuer la concentration inspirłe, allouer plus de temps pour la récupération \\
\hline Barbituriques, étomidate, propofol, alfatésine & Diminuer la dose initiale et la vitesse de la perfusion \\
\hline Morphiniques & $\begin{array}{l}\text { Deminuer la dose initiale; anticiper la prolongation de durée des effets systémiques et } \\
\text { épiduraux, l'incidence plus élevée de rigidité et de dépression respiratoire }\end{array}$ \\
\hline $\begin{array}{l}\text { Anesthésiques locaux pour la rachidienne et la } \\
\text { péridurale }\end{array}$ & Diminution minime à modérée des besoins segmentaires; prévoir la prolongation des effets \\
\hline Benzodiazépines & Deminuer légèrement la dose initiale; prévoir la prolongation des effets \\
\hline Succinylcholine & Diminuer légèrement la dose \\
\hline Relaxants non-dépolarisants & $\begin{array}{l}\text { Même posologie initiale ou légèrement augmentée; prévoir la prolongation de la durée } \\
\text { (excepté l'atracurium et le mivacurium) }\end{array}$ \\
\hline Néostigmine, édrophonium & Pas de changement de posologie; effets légèrement prolongés; anticiper des bradyarythmies \\
\hline Atropine & $\begin{array}{l}\text { Augmenter la dose pour obtenir une réponse adéquate sur la fréquence cardiaque; anticiper } \\
\text { l'excitation centrale postanesthésique }\end{array}$ \\
\hline $\begin{array}{l}\text { Epinéphrine, isoprotérénol, agonistes adrénergiques, } \\
\text { agonistes bêta }\end{array}$ & Augmenter la posologie \\
\hline
\end{tabular}

pour le besoin d'anesthésique est démontrée pour l'halothane, l'isoflurane, le cyclopropane et le desflurane. L'évolution temporelle de la baisse du besoin anesthésique semble identique pour tous les agents. Elle est done indépendante de l'agent. Il est possible que cette baisse soit en rapport avec des changements neurophysiologiques cérébraux, comme une réduction de la densité neuronale, mais elle est plus vraisemblablement causée par l'altération de la concentration des neurotransmetteurs cérébraux. En réalité, le besoin d'anesthésique pourrait être la seule mesure quantifiable de la réserve fonctionnelle du cerveau. Par exemple, on peut énoncer que le patient de 80 ans n'a besoin que de 65 à $75 \%$ de la concentration pour produire les mêmes effets que chez un adulte jeune (Tableau).

On rapporte aussi des changements relatifs à l'âge sur les besoins d'anesthésiques intraveineux, comme le thiopental et l'etomidate: ceux-ci pourraient provenir des concentrations plasmatiques initiales plus élevées que prévues qu'on observe dans les phases initiales de redistribution de ces agents du plasma vers les tissus. La réduction de la dose s'explique, en partie du moins, dans une conjoncture pharmacocynétique plutôt que pharmocodynamique. Cependant, d'autres études portant sur le rapport effets et concentration plasmatique des benzodiazépines et sur les effets des opiacé et du propofol en perfusion, supportent l'hypothèse d'une altération vraie de l'hémodynamie chez le sujet âgé, de la même façon qu'avec les agents inhalatoires.

Les modèles classiques à deux et à trois compartiments utilisés pour l'analyse pharmacocynétique du comporte- ment des anesthésiques intraveineux sont de moins bonsprédicteurs de réponses cliniques ponctuelles qu'on l'espérait. Ceci a conduit à une révaluation des hypothèses selon lesquelles lâge seul pouvait modifier les dimensions des volumes de distribution des drogues lipophiles et hydrophiles. Plus récemment, on a proposé de modifier les compartiments pharmacocynétiques traditionnels en mettant l'emphase sur les changements de transfert intercompartimentaux plutôt que sur les dimensions ou le nombre de compartiments dans le but prédire plus exactement la disposition des drogues chez les individus âgés. Le mécanisme des changements de vitesse de transfert est toutefois inconnu.

Les désordres les plus fréquents du système nerveux rencontrés dans la population gériatrique, les maladies de Parkinson et d'Alzheimer, reflètent des déficits de neurotransmetteurs spécifiques. La fréquence de ces affections peut être amplifiée par le processus normal de déplétion des neurotransmetteurs qui survient avec l'âge chez les sujets normaux. Pour le reste des désordres nerveux rattachés à l'âge, la maladie cérébro-vasculaire semble l'étiologie la plus fréquente: six pour cent de la population gériatrique chirurgicale a déjà subi un accident cérébro-vasculaire. L'ACV et d'autres affections neurologiques d'origine ischémique sont responsables de trois pour cent de la mortalité périopératoire chez ces patients. Cependant, le faible taux d'accidents cérébro-vasculaires rencontré dans la population chirurgicale âgée mais non tarée, suggère que l'autorégulation du débit sanguin cérébral n'est pas tellement compromise par l'âge luimême; malgré le fait que cette population ait une pré- 
disposition connue à l'instabilité hémodynamique et au dysfonctionnement autonome.

La barrière hémato-encéphalique demeure intacte fonctionnellement. Par conséquent, la cause la plus commune de l'altération de la conscience, de la désorientation, de l'instabilité autonome, de l'hyperréflexie ou des autres manifestations de la dysfonction postopératoire aiguë du système nerveux, demeure, chez le patient âgé, l'effet résiduel des drogues anesthésiques. Dans la population gériatrique chirurgicale, cette forme de morbidité anesthésique s'observe plus souvent que chez l'adulte jeune et elle persiste plus longtemps, parce quil existe avec l'âge une atteinte des systèmes responsables de l'élimination des drogues. De plus, la réduction de la réserve fonctionnelle du système nerveux central amplifie les conséquences des concentrations résiduelles dans les tissus de ces drogues puissantes.

\section{Système cardiovasculaire}

La fonction cardiovasculaire intégrée change moins que ne le font les structures anatomiques cardiaques et vasculaires. Les données classiques suggéraient le déclin implacable avec le vieillissement, de l'index cardiaque de repos. Des études plus récentes montrent que l'individu âgé actif et en bonne condition maintient un index cardiaque au repos à un niveau à peu près identique à celui du jeune homme. Le débit cardiaque s'abaisse légèrement mais en toutes proportions avec la masse musculaire et la surface corporelle typiques à l'âge avancé. A un niveau de demande normal, on ne trouve pas de réduction uniforme des vitesses de raccourcissement de la fibre myocardique ou de génération de la pression ventriculaire. En d'autres termes, le fonctionnement de la pompe reflète la condition physique et la demande aérobique plus que l'âge chronologique.

Chez le sujet âgé, le débit cardiaque augmente pendant l'exercice en partie par accélération de la fréquence, mais aussi par la capacité unique qu'a le ventricule gauche d'augmenter son volume diastolique en réponse à une hausse de la précharge, vraisemblablement par le mécanisme de Frank-Starling. Chez le sujet jeune, par contre, l'augmentation du débit cardiaque survenant pendant l'exercice provient de l'accélération de la fréquence et de l'augmentation de la fraction d'éjection par la stimulation des composantes nerveuses et humorales du système sympathico-adrénergique. Cependant, les effets chronotropes et inotropes des bêta-agonistes sont réduits de façon importante chez la personne âgée. On peut considérer le vieillissement comme un état de blocage-bêta progressif. Le baroréflexe responsable de l'augmentation de la vélocité de la contraction myocardique chez le jeune adulte diminue avec l'âge avancé. Comme la puissance des agonistes adrénergiques et de leurs antagonistes di- minue avec l'âge avancé, on croit que c'est la détérioration de la qualité du récepteur adrénergique et non le déclin du nombre des récepteurs qui est le mécanisme responsable de ces changements.

Chez l'individu âgé en bonne santé, l'autre changement cardiovasculaire important consiste en la perte d'élasticité des grosses artères: ce qui conduit à un durcissement de l'arbre artériel. Comme conséquence, on constate une montée progressive de la tension artérielle systolique avec un élargissement de la différentielle. Cette augmentation de l'impédance à l'éjection systolique produit une hypertrophie concentrique de la paroi du ventricule gauche. L'infiltration fibrotique des voies de conduction cardiaque prédispose aux retards de conduction et à l'ectopie ventriculaire. La perte d'élasticité et les changements fibrotiques d'un coeur déjà hypertrophié réduisent encore plus la compliance ventriculaire: ceci rend le coeur àgé à la fois sensible et intolérant à l'effet volume. Parce que de petites fluctuations de volumes de retour veineux produisent de grands changements de la pression de précharge, les patients avancés en âge sont particulièrement prédisposés à l'hypotension artérielle par le blocage du retour veineux. Par contre ils sont sujets aux augmentations rapides de la pression diastolique et à la distension des chambres cardiaques causée par l'augmentation du retour veineux. La perte de la contribution auriculaire par fibrillation peu compromettre dangereusement le volume d'éjection et le débit cardiaque.

La diminution de l'élasticité artérielle se manifeste même dans les populations âgées où l'athéromatose est virtuellement inconnue. Toutefois, dans notre société où le régime alimentaire et les conditions environnementales prédisposent à l'hypertension et la maladie vasculaire artériosclérotique, celles-ci demeurent les pathologies les plus répandues de la population chirurgicale gériatrique. La moitié de tous les patients âgés portent des signes de cette affection qui est responsable d'une mortalité périopératoire de $10 \%$ pour ce groupe d'âge.

\section{Le système respiratoire}

Les conséquences du vieillissement sur la fonction pulmonaire, bien que complexes, pourraient être en général attribuées à une perte généralisée du recul élastique du poumon. Même chez le patient avancé en âge libre de toute affection pulmonaire, une augmentation de la compliance identique à celle de l'emphysème perturbe l'équilibre du rapport ventilation/perfusion. Bien que la diffusion elle-même demeure inchangée, la mauvaise distribution du débit sanguin pulmonaire relativement à la distribution du débit gazeux produit une chute de tension de l'oxygène avant, pendant et après la chirurgie. L'excrétion du gaz carbonique n'est pas affectée, et la $\mathrm{PaCO}_{2}$ demeure au même niveau chez le sujet âgé que 
chez le jeune adulte, ce qui suggère un contrôle ponctuel et normal et de la réponse au $\mathrm{CO}_{2}$. Cependant, le sujet âgé est incapable d'hyperventiler comme les enfants et les adultes en réponse à l'hypoxémie et à l'hypercapnie; cette caractéristique du patient âgé est donc susceptible de conduire à une défaillance ventilatoire périopératoire imprévisible.

Malgré la perte de l'élasticité pulmonaire et de l'augmentation de la compliance pulmonaire, le volume pulmonaire change peu car la compliance de la paroi thoracique diminue parallèlement en vertu de la fibrocalcification progressive de la cage thoracique. L'atrophie des intercostaux ajoute à la baisse d'efficacité du soufflet thoracique. La mécanique pulmonaire devient restrictive avec l'âge, comme le montrent la chute du VEMS et du débit maximal mesuré à mi-expiration (DMME). Environ $15 \%$ de la population gériatrique se présente avant l'opération avec un certain degré de maladie pulmonaire obstructive chronique. La maladie pulmonaire établie et le site de la chirurgie sont connus depuis longtemps comme les meilleurs prédicteurs de la morbidité et de la mortalité postopératoire.

\section{Système urinaire}

Le vieillissement altère la fonction rénale de façon importante parallèlement à létat des vaisseaux rénaux. Malgré la perte peu importante de la masse rénale cellulaire (10-20\% à l'âge de quatre vingts ans), la vieillissement produit par décennie d'âge une diminution linéaire de 6-8\% du taux de filtration glomérulaire. Quand on mesure chez le volontaire en bonne santé, le débit sanguin et plasmatique rénal sur de longues périodes, on constate une baisse progressive avec l'âge. A 80 ans, ces paramètres tombent de moitié si on les compare à ceux des jeunes adultes. La fraction de filtration, cependant, augmente légèrement compensant ainsi pour la réduction de la perfusion rénale. Anatomiquement, on trouve un degré modéré d'oblitération glomérulaire et un dérangement de l'architecture vasculaire rénale, avec une perte importante des néphrons fonctionnels. La sécrétion tubulaire et la réabsorption des drogues et des autres substances solubles diminuent en proportion. La vitesse et l'ordre de grandeur de la réponse réno-hypophysaire à la déshydratation sont considérablement affectés avec incapacité de concentrer l'urine et de conserver l'eau.

On ne peut ordinairement pas détecter cette perte de fonction avec les tests de laboratoire usuels. La perte de charge créatinique qui suit la réduction de la masse musculaire squelettique se traduit par des concentrations de créatinine sérique qui sont identiques à celle des jeunes adulte. Ainsi, normalement, bien que la fonction rénale résiduelle soit suffisante pour éviter l'urémie, la réserve fonctionnelle rénale qui permettra de faire face à une charge hydrique supplémentaire ou à un déséquilibre électrolytique est limite. Linsuffisance rénale est en réalité responsable pour au moins le cinquième de la mortalité périopératoire du patient âgé. Les conséquences pharmacologiques des changements attribuables à l'âge avancé sont plus importants: la demi-vie d'élimination $t_{1 / 2} \beta$ de presque tous les drogues anesthésiques et de leur métabolites normalement éliminés par le rein est prolongée, surtout chez ceux dont la fonction rénales est déjà atteinte.

\section{Le système hépatique}

Les changements qualitatifs de la fonction hépatique attribuables au vieillissement sont peu nombreux. L'activité enzymatique semble bien préservée à part la synthèse hépatique de la cholinestérase plasmatique qui paraît déprimée chez l'homme âgé. Les femmes âgées, par contraste, semblent capables de maintenir leur fonction enzymatique au même niveau que les jeunes adultes. Elles sont, par contre, plus susceptibles que les hommes aux manifestations de l'induction enzymatique causées par la cigarette, laquelle peut augmenter le rythme de la biotransformation des drogues. Le vieillissement réduit le volume hépatique de sorte qu 40-50\% de la masse hépatique de l'adulte jeune subit une involution vers l'âge de 80 ans avec une réduction proportionnelle du débit sanguin.

Cette perte de tissu hépatique bien perfusé explique en partie la baisse de la vitesse de la clearance des drogues anesthésiques et de leur adjuvants qui dépendent de la biotransformation et surtout ceux qui utilisent le mécanisme du premier passage. La durée des effets cliniques de ces agents intraveineux peut être encore plus prolongée si leurs métabolites primaires et secondaires doivent subir l'élimination rénale. Le dysfonctionnent et l'insuffisance hépatiques ne surviennent que dans une petite mais significative fraction (4\%) de cette population. Des degrés plus subtils de malfonction ou de limitation de réserve fonctionnelle expliquent plusieurs complications postopératoires et peuvent nécessiter une thérapie de soutien et des soins intensifs.

\section{L'axe sympathico-surrénalien}

A l'âge avancé, l'épinéphrine et la norépinéphrine plasmatiques augmentent uniformément et de façon importante au repos et en réponse au stress. Cependant, les sujets âgés ne semblent pas fonctionnellement « hyperadrénergiques " parce que les hauts niveaux des catécholamines sanguines compensent partiellement pour la perte de réactivité des récepteurs autonomes. Il ne semble pas y avoir de régulation " à la baisse " des récepteurs adrénergiques malgré une exposition augmentée à leurs molécules agonistes. On ne sait pas trop si ces phénomènes sont attribuables à une perte d'affinité entre 
catécholamines et récepteurs périphériques, ou si la capacité réduite de réponse des effecteurs représente une défaillance de l'activation de l'adénylate cyclase au niveau cellulaire.

Quelque soit le mécanisme, les points-repères déterminés par l'homéostase hypothalamique de la pression artérielle et la fréquence cardiaque ne changent pas avec l'âge, mais les systèmes autonomes commencent à se comporter comme des systèmes sous-modulés: la pression artérielle oscille beaucoup plus que celles des jeunes adultes. L'hypotension et l'hypertension provoquent des réponses réflexes moins marquées, moins à propos et moins efficaces sur la fréquence cardiaque. En conséquence, les anesthésiques et les techniques qui ont déjà tendance à déprimer les effecteurs du système nerveux autonome, abaissent la concentration des catécholamines endogènes, bloquent les ganglions et provoquent une sympathectomie pharmacologique de sorte que l'hypotension est plus fréquente et plus grave que celle des jeunes adultes. De la même façon, l'hypertension provoquée par le stimulus chirurgical sera plus extrême et plus prolongée.

\section{La structure corporelle}

La sénescence se manifeste au niveau de la structure corporelle par un processus mal compris de déshydratation cellulaire, avec atrophie des muscles squelettiques et augmentation de la fraction lipidique de la masse corporelle totale. Des études révèlent qu'en moyenne six $\mathrm{kg}$ de muscle squelettique sont perdus, cinq $\mathrm{kg}$ de tissu adipeux sont gagnés et que l'eau corporelle totale est diminuée de $12 \%$ à l'âge de 80 ans. Ces changements sont plus importants chez la femme que chez l'homme. Ils influencent la pharmacocynétique des anesthésiques en augmentant la fraction de la masse corporelle qui sert de réservoir aux molécules des drogues liposolubles. Si on augmente le volume de distribution d'un opiacé ou de tout agent liposoluble, le temps requis pour son élimination est augmenté même si la clearance plasmatique demeure normale. Si en plus la clearance est défectueuse par perte de tissu rénal ou hépatique, comme il arrive pendant la vieillesse, le résultat net consiste en une prolongation du $t_{1 / 2} \beta$ avec effet prolongé de la drogue. Seules les molécules qui possèdent une haute solubilité pour les compartiments lipidiques spécialisés comme le cerveau et la moelle épinière ou ceux qui ont de très fortes affinités pour les récepteurs ne présentent pas de changements de volumes de distribution.

\section{L'état physique et le pronostic anesthésique}

La mortalité associée à l'âge est plus élevée chez le sujet âgé que chez le jeune adulte. Des révisions récentes de données de mortalité périopératoire en fonction de l'état physique révèlent que ce sont les maladies rattachées au vieillissement et non le vieillissement lui-même qui sont en cause. Chez le patient en stage terminal de maladie grave ou qui présente une défaillance multiviscérale, la perte de l'hémostase autonome due au vieillissement agit comme un facteur supplémentaire de risque. Il nyy à pas d'anesthésie idéale pour le patient âgé. Des études prospectives, randomisées et très étendues de la pratique anesthésique n'ont pas démontré d'avantages significatifs entre l'anesthésie régionale et la générale. La même considération s'applique au choix de l'agent. Cependant, la sympathectomie pharmacologique produite par l'epidurale pour diminuer le stress et la douleur chirurgicale semble réduire de façon importante la morbidité postopératoire.

On doit ne plus considérer l'âge comme une contreindication à l'anesthésie et à la chirurgie. Un grand progrès sera réalisé lorsque nous saurons mieux identifier les affections rattachées à l'âge qui, contrairement à l'âge lui-même, sont les causes réelles de l'augmentation du risque opératoire.

\section{Références}

(Voir page R67) 